\title{
TANULÁS, TANULÁSKUTATÁS ÉS OKTATÁSPOLITIKA
}

\section{HALÁSZ GÁBOR}

az ELTE PPK Felsőoktatás-menedzsment Intézeti Központjának

egyetemi tanára

halaszg@helka.iif.hu

\begin{abstract}
E tanulmány célja annak elemzése, milyen kihívásokkal kell szembenézniük a tanulás eredményessé tételét középpontba helyezö oktatáspolitikáknak, továbbá - az e területen sikeres ország tapasztalatai alapján - annak bemutatása, konkrétan mi jellemezi az ilyen oktatáspolitikákat. A szerzö kiemeli: tanuláscentrikus oktatáspolitikák elsösorban azokban az országokban alakulnak ki, amelyek felismerik a tanulásnak a gazdasági fejlödésben és vállalkozásaik piaci versenyképességében játszott szerepét. Különbséget tesz a tanulás „formális” és „,autentikus” módja között és a tanulás eredményessé tételét középpontba helyezö oktatáspolitikák egyik fontos vonásának tekinti azt, hogy arra törekszenek, kivétel nélkül minden tanulónál eredményes, ,, autentikus” tanulásra kerüljön sor. Az ilyen oktatáspolitikák fontos jellemzőjeként írja le többek között a tanuláskutatás eredményeinek a hasznositását, a tanulásszervezési módszereknek a figyelem elöterébe kerülését, az értékelési rendszerek megfelelö átalakitását, az iskolai szervezet- és vezetésfejlesztés középpontba helyezését, mindezek segítségével az iskolák intelligens tanulószervezetté alakitását, valamit a nemzeti oktatáskutatási és innovációs rendszerek fejlödésének támogatását.
\end{abstract}

A közelmúltban az egyik egyetemi kurzusom felnőtt hallgatója, miután a jegyét az indexébe beírtam és a tudását megdicsértem, elmondta, milyen nagy örömet talált a vizsgára való készülésben. „Az volt a jó, hogy nem kellett tanulni!” - mondta. „Hogy érti ezt?” - kérdeztem csodálkozva. - „Hiszen éppen most mesélte el, mennyi új dolog tárult fel maga elött, és milyen sok új dolgot értett meg." Kicsit gondolkodott, majd folytatta: ,Igen, de ez más volt. Azt akartam mondani, hogy csak olvastam a feladott szövegeket, gondolkodtam rajtuk, és nem kellett külön tanulnom a vizsgára."

Azt gondoltam, a vizsgázóm egyike azoknak, akik számára a „tanulni” szó azt a tevékenységet jelenti, amit akkor csinálunk, amikor - általában valamilyen iskolai „,számonkérésre” készülve - megpróbálunk valamit módszeresen az emlékezetünkbe vésni. Azt, hogy korábban nem látott új dolgok tárultak fel előtte, és olyan összefüggéseket fedezett fel, amelyekről korábban nem volt sejtelme, a szó megszokott értelmében nem tekintette tanulásnak. Mintha külön erre nem is lett volna szava: csak körülírással tudta ezt az élményt elmagyarázni. Hozzá kell tennem: ez a felnőtt hallgató gyakorló pedagógus volt: egy kudarcos gyerekekkel foglalkozó is- 
kolában dolgozott, és azért jött az egyetemre, hogy neveléstudományból szerezzen diplomát.

\section{A tanulás szó kétféle értelme}

Az elmúlt évtizedben számos fejlett országban láttuk azt, hogy a „tanulás” az oktatáspolitikai közbeszéd egyik leggyakrabban használt szavává vált. A tanulás fejlesztését célzó reformok sokaságát indították el, és olyan eszközöket próbáltak mozgásba hozni, amelyektől a tanulás eredményességének a javulását várták. Azok, akik ezeket a törekvéseket kezdeményezték, általában nem azt értették tanulás alatt, amit az én egyetemi hallgatóm.

A hallgatóm valami olyasmit értett ez alatt, mint az a diák, aki a sikertelen iskolai felelés után őszinte méltatlankodással mondja: „,De hát én tanultam, tanár úr!" Igazságtalannak érzi a rossz jegyet, hiszen megdolgozott a jobb jegyért. Hoszszú órákat töltött tankönyvekkel a kezében, és komoly erőfeszítéseket tett annak érdekében, hogy emlékezetébe vésse az elolvasott dolgokat. Ezeket a feleletében talán korrekt módon el is ismételte, ám amikor kapott egy szokatlan kérdést, arra nem tudott válaszolni. „De hát ez a kérdés nem is volt benne a tankönyvben!” gondolta. „Milyen jogon kérdez tölem a tanár olyasmit, amit nem is tanultunk, ami nincs is benne a tananyagban?"

Mindez jól mutatja, hogy a tanulás szónak legalább kétféle értelme van a számunkra. Jelölheti a tanulás ismert iskolás formáját is - mint az én egyetemistám számára -, de jelölheti azt is, ami például egy csecsemővel történik, amikor a kezét nézegeti, vagy azt, ami Pavlov kutyájával történt. Vagy még tágabban: jelölheti azt is, ami megtörténik minden olyan - akár élő, akár élettelen - rendszerrel, amely valamilyen módon érzékeli a környezete változásait, és képes ezekhez adaptálódni (Nahalka, 1998). Az első értelemben a tanulás jellegzetes formája az iskolában kapott feladatok végrehajtása, amit tudatosan végzünk, a második értelemben viszont olyan dologról van szó, amely akárhol megtörténhet velünk, és nem is feltétlenül tudunk róla. Lehet, hogy tanulunk a szó első értelmében, de a szó második - mondjuk úgy, hogy autentikus - értelmében nem történik velünk tanulás: a tudatunkban, a személyiségünkben nem történik említésre méltó változás. ${ }^{1}$

A két jelentés persze nem független egymástól. A tanulás iskolai - azaz szabályozott, tervezett, tudatos - formájának is természetesen célja az, hogy bekövetkezzen a második értelemben vett, vagyis az autentikus tanulás. A gond az, hogy a tapasztalat azt mutatja: miközben az első értelemben vett tanulás jól láthatóan zajlik a szemünk elött, arról nem könnyü meggyőződni, vajon történt-e a második érte-

\footnotetext{
${ }^{1}$ Az a különbség, amelyet itt a „formális” vagy „iskolás” és az „autentikus” tanulás között teszek, ha nem is pont ugyanaz, mint amit olyan tanuláskutatók, mint Ferenc Marton vagy Noel Entwistle tettek a „felszínes” és a „mély” tanulás között, nagyon hasonlít arra.
} 
lemben vett tanulás. Sőt, ami ennél is nagyobb probléma: azok, akiknek „hivatalból" feladata a tanulás megszervezése, gyakran nem is nagyon törődnek azzal, hogy ez a második értelemben is bekövetkezik-e. Ezt akár tudatosan is tehetik, sőt akár bölcs megfontolásból is, tudva azt, hogy úgysem lennének képesek komolyan ellenőrizni vagy befolyásolni az emberi tanulás végtelenül komplex világát. Ezért van az, hogy - ahogy Richard Elmore, a Harvard Egyetem professzora, a tanuláscentrikus oktatáspolitikák egyik ihletője megfogalmazta - ,az oktatásirányitók nem a tanulás menedzselésével foglalkoznak, hanem a tanulást körülvevö struktúrák és folyamatok menedzselésével" (Elmore, 2000, 6. o.).

A tanulás két értelmének egymástól való elszakadása a „tanítás” és a „tanulás” egymástól való elválásában is megjelenik. A tanítást könnyebb tudatosan alakítani, racionálisan megszervezni és ellenőrizni, mint a végtelenül komplex, egyénröl egyénre eltérő módon zajló tanulást. Annak a leírása, hogy mit kell tennie a tanárnak ahhoz, hogy azt mondhassuk rá, ő most tanít, sőt „megfelelően” tanít jóval egyszerübb, mint annak a leírása, hogy mit kell tennie a tanulónak ahhoz, hogy elmondhassuk róla, ö most (a szó második értelmében) tanul. John Cowan a felsőoktatás-pedagógia egyik ismert szakértője szellemes, de találó módon így fogalmazta meg, mit ért tanítás alatt: „Tanitás alatt azt értem, amikor céltudatos módon olyan helyzeteket hozunk létre, amelyekböl a motivált tanulók nem tudnak úgy kiszökni (escape), hogy ne tanuljanak vagy fejlödjenek" (Cowan, 2004, 61. o.). A tanítás és a tanulás egymástól való elszakadását szemléletesen fejezte ki az a tréfás történet, amelyet a tanulásorientált oktatáspolitikák egyik másik, Magyarországon is ismert szakértőjétől, David Hopkins-tól hallhattunk néhány évvel ezelött. E történet arról a tanárról szól, aki az osztályteremben állva ezt mondta a diákoknak: „Az én feladatom az, hogy tanitsak, a ti feladatotok az, hogy tanuljatok, s ha ti elöbb végeztek, szóljatok." (Hopkins, 2004). Az én egyetemistám szavai is a két jelentés elszakadásáról tanúskodtak.

Azok az oktatáspolitikai vagy oktatásfejlesztési törekvések, amelyekkel ma a fejlett világ számos országában találkozunk, a tanulás szót egyértelmüen a második értelemben használják. E törekvések egyik célja éppen az, hogy az egymástól elszakadt kétféle jelentést megpróbálják újra összekapcsolni. Azaz megpróbálják az iskolák világát úgy alakítani, hogy ott minél inkább a második értelemben vett tanulás is folyjék. Ez persze végtelenül bonyolult feladat. A tanulás komolyan vétele, és az ennek érdekében mozgósított eszközök sokaságának a megjelenése a modern államok oktatáspolitikájának egyik legjellegzetesebb és ugyanakkor legtöbb kérdést fölvető jellemezője. 


\section{A tanuláscentrikus oktatáspolitikák gyökerei}

Ebben a tanulmányban azokat az oktatáspolitikákat nevezem tanuláscentrikusnak, amelyek akár explicit, akár implicit módon felismerték és elfogadták a formális (az első értelemben vett) és az autentikus (a második értelemben vett) tanulás közötti különbséget, és arra tesznek határozott kísérletet, hogy az utóbbit támogassák. Az ilyen - és ennek a célnak megfelelően kidolgozott eszközrendszert alkalmazó - oktatáspolitikák ma elsősorban az angolszász és az észak-európai országokat jellemzik, de nyugodtan elmondhatjuk, hogy emellett a megközelítés mellett az Európai Unió is jelentős részben elkötelezte magát. ${ }^{2}$

\section{A mindennapi gondolkodás feltételezései, amelyeken az iskolázás nyugszik}

- A tudás a világban található tények gyüjteménye és olyan eljárásoké, amelyek problémák megoldását szolgálják. A tények olyan állításokban ragadhatóak meg, mint például: „A Föld 23,45 fokos dőlésü tengely körül forog." Az eljárások pedig olyan lépésről lépésre követett instrukció sorok, mint például: „A több számjegyü összeadásnál a maradékot a következő oszlopba kell átvinni".

- Az iskolázás célja a tények és eljárások bevitele a tanulók fejébe. Az embereket akkor tekintik iskolázottnak vagy tanultnak, ha a tények és eljárások nagy mennyiségét birtokolják.

- A tanárok azok, akik ismerik a tényeket, az eljárásokat, és az a feladatuk, hogy ezeket átadják a tanulóknak.

- Először az egyszerübb tényeket és eljárásokat kell megtanulni, majd ezt követően az összetettebbeket. Az „egyszerüség” és az „összetettség” meghatározása, továbbá a tananyag ennek megfelelö szekvenciális felépítése a tanárok és a tankönyvszerzők dolga, akik elsősorban szakértőkkel, például matematikusokkal, természettudósokkal vagy történészekkel konzultálnak, és nem abból indulnak ki, hogy a gyerekek hogyan tanulnak.

- Azt, hogy az iskolázás sikeres volt-e, oly módon tudjuk megállapítani, hogy teszteljük, vajon a tanulók a tények és eljárások mekkora mennyiségét sajátították el (Sawyer, 2008).

A tanuláscentrikus oktatáspolitikák paradigmatikus váltást próbálnak meg végrehajtani az iskolázásnak a tizenkilencedik században kialakult és ma is élő mintájá-

\footnotetext{
${ }^{2}$ Lásd a 2008-ban széles körü vitára bocsátott „Schools For The 21st Century” című bizottsági dokumentumot (European Commission, 2007) és ennek nyilvános vitáját (http://ec.europa.eu/education/school21/index_en.html).
} 
val szemben. Azzal a mintával szemben, amelynek egyik legfontosabb jellemzője Keith Sawyer, a Washingtoni Egyetem egyik ismert, kreativitás-kutatással és tanuláskutatással foglalkozó professzora szerint az, hogy akkor alakult ki, amikor az emberi tanulás természetéről még alig tudtunk valamit. Sawyer szerint az iskolázásnak ez a paradigmája néhány egyszerü, a mindennapi gondolkodás számára kézenfekvő, ám semmilyen tudományos kutatás által nem igazolt feltételezésre épült (lásd a keretes szöveget).

Az autentikus tanulásnak az iskolázás középpontjába állítása első hallásra magától értetődőnek és egyszerünek tűnik. A valóságban ez kérdések és gyakorlati nehézségek sokaságát veti fel. Ezek közül az első mindjárt az, hogy az iskola nemcsak a tanulás célját szolgálja, hanem egy sor egyéb, jól vagy kevésbé jól látható célt is, és a társadalmak nyílt vagy burkolt formában e célok szolgálatát is határozottan megkövetelik tőle. Kicsit durván fogalmazva szinte azt is mondhatnák, az iskola nem arra, de legalábbis nem csak arra lett ,kitalálva”, hogy a tanulást szolgálja. Az iskola többfunkciós intézmény, amely szolgálja többek között a létező kulturális minták valamelyikének uralkodó helyzetbe hozását, a társadalmi rétegződés újratermelését vagy éppen megváltoztatását, a munkaerőnek a gazdaság különböző szektorai között történő elosztását, a politikai rezsimek társadalmi elfogadtatását, a gyermekek megőrzését, a társadalmi szolidaritás és kohézió fenntartását és egyebeket. A tanulás eredményes megszervezése csupán egyike az iskola funkcióinak, és a különböző funkciók - pontosabban az ezek eredményes müködésében érdekelt társadalmi csoportok - közötti versengésben egyáltalán nem biztos, hogy éppen ez a funkció kap prioritást. Igaz, e funkció eredményes gyakorlása különösen sok társadalmi csoportnak érdeke, így e mellé viszonylag könnyen szerveződhet megfelelő politikai támogatást biztosító koalíció (legalábbis addig, amíg a tanulást valóban eredményesen megszervező iskola költségei nem válnak nyilvánvalóvá).

Számos jel utal arra, hogy az elmúlt évtizedben az oktatáspolitika erőtere egy sor fejlett országban úgy alakult, ami kedvezett a tanuláscentrikus oktatáspolitikák kialakulásának. Ennek egyik legfontosabb oka valószínüleg az, hogy a technológiai fejlődés és a termelési folyamatok átalakulása nyomán a gazdaság egyre több szereplöje számára vált fontossá az emberi erőforrások, azaz a munkaerő minősége: ezen belül különösen az, hogy a munkavállalók milyen tanult képességekkel ${ }^{3}$ rendelkeznek. A munkaerő tanult képességeinek minősége a gazdaság és a gazdaságuk versenyképességéért aggódó államok számára természetesen mindig fontos volt, és a technológiai fejlődés ennek jelentőségét korábban is mindig növelte. Az elmúlt évtizedben azonban a globalizálódás átalakította azt az erőteret, amelyben a társadalmak mindezt érzékelik és értelmezik. Számos országban alakult ki viszonylag stabil konszenzus azzal kapcsolatban, hogy a gazdaság szereplőinek globális versenyképességét alapvetően meghatározza a munkaerö tanult képességeinek a szint-

\footnotetext{
${ }^{3}$ Ebben a szövegben a „tanult képességek” szó jelentése körülbelül az, ami az angol skill szóé.
} 
je, és hogy ennek hiányosságai arra ítélhetnek egy-egy országot, hogy tartósan beleszoruljon a globális piac alacsonyabb jövedelmezőségü szegmenseibe. ${ }^{4}$

Azt, hogy a tanult képességeknek milyen nagy szerepe van a vállalatok versenyképességében, és e szerep jelentősége milyen gyorsan nő, talán semmi sem mutatja jobban, mint azon erőforrások nagyságának az alakulása, amelyeket a vállalatok a saját munkaerejük képzésére fordítanak. Az angol szakszervezeti szövetség elemzése szerint például 2000 és 2007 között 65 százalékkal (24 milliárd fontról 39 milliárd fontra) nőtt azoknak a kiadásoknak a nagysága, amelyet a munkáltatók a munkavállalók képzésére fordítanak, és ezen belül különösen nagy arányban nőttek a közvetlen belső képzésre fordított kiadások (TUC, 2008). A KSH adatai szerint 1999 és 2005 között Magyarországon 37 százalékról 49 százalékra nőtt a képzést támogató vállalkozások aránya $(K S H, 2007)$. Erre azért is érdemes odafigyelni, mert a versenyszférában a munkaerő képzésére nem vagy kevésbé rakódnak rá olyan egyéb funkciók, amelyekröl az iskolai oktatással kapcsolatban korábban szó volt. Itt akkor éri meg a tanulásba befektetni, ha valóságos tanulás történik, azaz a munkaerő tanult képességei ténylegesen javulnak. Nem véletlen, hogy a vállalati képzési rendszerekben folyó tanulást - kifejezetten a tanulás minősége szempontjából -, sokan jóval eredményesebbnek tartják, mint a formális iskolarendszeren belül történő képzést. Ennek egyik látványos jele az, hogy rendkívül versenyképes kelet-ázsiai vállalatok számára természetes, hogy a saját munkaerejük szakmai képzését nem bízzák külső képzőkre, hanem azt közvetlenül maguk szervezik (Ashton et al, 2000; Young-Hyun, 2007).

A tanuláscentrikus oktatáspolitikák kialakulását, azaz a tanulásnak az oktatáspolitika középpontjába helyezését a gazdaság sajátos módon egy másik irányból is támogatja, és ez nem kevésbé érdemel figyelmet. A tanult képességek piaci felértékelődése kedvez annak, hogy kialakuljon a tanulás piaca, ahol egymással olyan szereplök versengenek, akik azt ígérik, hatékonyan és eredményesen képesek fejleszteni az egyének tudását vagy a képességeit. A tudás- vagy képességfejlesztés olyan szolgáltatási termékké vált, amelynek - mint minden más terméknek - a piaci értékét alapvetően meghatározza a minősége. Vagyis a tanulás piacán elsősorban azok a képzések válhatnak sikeres „termékké”, amelyek ténylegesen és hatékonyan javítják a képzésben részt vevők tudását és képességeit. Fontos persze hozzátenni, ez a piac is tele van „hamis termékekkel”, vagyis olyan képzési szolgáltatásokkal, amelyek valójában csak ,papírhoz” juttatják az azokat igénybe vevőt (aki nem egyszer eleve csak ezt akarja), és tényleges képességfejlesztést alig nyújtanak. Ez azonban nem változtat azon, hogy e piac számos szegmensében közelít egymáshoz a formális tanulás és a tényleges tanulás, hiszen normális esetben azok, akik az ok-

\footnotetext{
${ }^{4}$ Különösen látványosan volt ez megfigyelhető az elmúlt években az Egyesült Királyságban, ahol az „alacsony képességek - alacsony jövedelem” egyensúlyi helyzetbe történő beszorulástól való félelem rendkívüli politikai energiákat szabadított fel, elindítva azt a folyamatot, amelyet gyakran „képességforradalomnak" neveznek (World Class Skills, 2007).
} 
tatási szolgáltatás költségeit állják, nem vásárolják meg azt az oktatást, amely nem biztosít tényleges tanulási lehetőséget.

A tanulás piacán persze, mint hangsúlyoztuk, nem csak vevők (tanulók) vannak, hanem egymással versengő eladók (képzési termékeket értékesítők) is, akik új és új termékekkel próbálnak piaci befolyást szerezni. Az elmúlt években egyre több új szereplő lépett be erre a piacra, és e szereplők gyakran a formális tanulás felől a valóságos tanulás felé tolták el a tanulásról való gondolkodást. Ezen a területen talán három olyan fejleményt érdemes hangsúlyozni, amelyek a jövőben alapvető módon alakíthatják az oktatásról való gondolkodásunkat. Az első a nem-formális és informális tanulás során szerzett képességek elismertetésének kiemelt oktatáspolitikai céllá válása (Colardyn és Bjornavold, 2004; Schuur et al., 2005). A második az olyan ,vállalati egyetemnek” nevezett iskoláknak a megjelenése, amelyek eredetileg általában saját munkavállalók belső képzésére jöttek létre, de később megnyitották kapuikat a nyilvánosság előtt és egyre gyakrabban a nyilvános diplomák kiadásának a jogát is megszerzik. ${ }^{5} \mathrm{Az}$ ilyen vállalati egyetemekre általában a képességfejlesztő vagy „kompetencia-alapú” orientáció a jellemző (Kováts, 2002). A harmadik jellegzetes trend a nagy informatikai cégek fokozatos behatolása az iskolai oktatás világába, ami ma már egyre kevésbé csak hardvereladást jelent, és egyre inkább a tanulást eredményesen szolgáló pedagógiai technológiák terjesztését és értékesítését is. Ennek egyik látványos megnyilvánulása volt legutóbb az, amikor a világ két meghatározó tanulói eredményességet mérő szervezete, illetve programja (az IEA és a PISA) és három globális informatikai óriáscég 2009 elején megegyezett az értékelési-mérési rendszerek közös fejlesztéséröl (lásd Partners in Education Transformation, 2009).

A gazdaság világában zajló tanulást sok szempontból más logika irányítja, mint az iskolák világában zajló tanulást. A gazdaságban, különösen annak leginkább versenyképes szervezeteiben zajló tanulásra - aminek szervezését egyre inkább erre a területre szakosodott és magasan képzett professzionális személyzet végzi - alapvetően a képességfejlesztésben vagy kompetenciafejlesztésben történő gondolkodás jellemző (Delamare és Winterton, 2005), és ez jóval erősebb, mint ami az iskolák világát jellemezi. A gazdasági szervezetekben folyó tanulás ma már messze nem csak szorosan vett szakmai vagy technológiai képzést jelent, hanem gyakran olyan általános képességek közvetlen fejlesztését, mint amilyen például az együttmüködési, kommunikációs vagy problémamegoldó képesség, és e tanulás gyakran elválaszthatatlanul összeolvad a munkavégzéssel. Ebben a kontextusban a tanulás valóban a képességek fejlesztését jelenti, és akik ennek az eredményességéért felelnek, előbb inkább a fejlesztendő képességeken kezdenek el gondolkodni,

\footnotetext{
${ }^{5}$ A Wikipedia e témában írott szócikke szerint 1994 és 2001 között a vállalati egyetemnek (corporate universities) intézmények száma 400-ról 2000-re nőtt. Néhány országban (például Dél-Korea és Egyesült Királyság) ezek szervezetek megkaphatják a nyilvános felsőoktatási diploma (általában a legalacsonyabb szintü felsőfokú vagy fél-felsőfokú végzettség) kiadásának jogát.
} 
és csak utána azon, hogy miképpen lehet a fejlesztést a gyakorlatban úgy megszervezni, hogy a bonyolult képességek valóban kialakuljanak a tanuló emberekben.

Az eddigiekkel azt szerettem volna jelezni, hogy annak a változásnak, amely az elmúlt évtizedben az oktatáspolitika erőterében lezajlott, és amely a tanuláscentrikus oktatáspolitikák megerősödéséhez vezetett, a gyökerei jelentős részben a formális oktatás világán kívüli tanulás felértékelődésében találhatóak. Ez a tanulmány azonban elsősorban a gyökereknek egy másik ágára próbálja felhívni a figyelmet: ez az a robbanásszerü fejlődés, amely emberi tanulásról való tudásunkban történt az elmúlt évtizedekben, az agykutatás, a kognitív idegtudományok és az ezekre épülő tanuláskutatás (learning science) eredményeinek köszönhetően. Úgy vélem, az eddig említett, a gazdaság világában zajló folyamatok nélkül e tudás önmagában nem lett volna elég erős ahhoz, hogy átrendezze az oktatáspolitika erőterét, ugyanakkor az itt bemutatott külső hatások nyomán átrendeződő erőtérben e tudás értéke és hatása is nagymértékben megnőtt. Ennek az új tudásnak a fényében ma néha szinte abszurdnak és érthetetlennek érezzük, miképpen szerveződhetett meg az emberi tanulás legfontosabb intézménye, az iskola úgy, ahogyan a tizennyolcadik és tizenkilencedik században megszerveződött, és ahogyan mai formájában továbbra is müködik. E tudás felöl nézve gyakran olyan érzésünk támad, mintha az iskolák nem segítenék, hanem gátolnák az emberi tanulást: legalábbis annak azt a formáját, amelyet korábban autentikusnak neveztem. Innen nézve néha nem értjük, miért nevezik ,alternatívnak” a tanulásszervezésnek azokat a formáit, amelyeknek akár a fóáramot meghatározóak is lehetnének (Sliwka, 2008).

A Keith Sawyer a korábban már idézett tanulmányában sorra veszi a tanuláskutatásnak azokat az eredményeit, amelyek átalakították a tanulásról való gondolkodásunkat. Ezek közül itt csupán néhányat emelnék ki: olyan elemeket, amelyek sokakat elgondolkodtattak arról, vajon mennyiben képes az iskola annak mai formájában a gyermeki tanulást segíteni, és sokakat késztetett arra, hogy olyan politikákban kezdjenek gondolkodni, amelyek az iskolákat a tanulás számára kedvezőbb környezetté alakíthatják.

A tanuláskutatás talán leggyakrabban idézett eredménye az elözetes tudás meghatározó jelentőségének felismerése. Annak megértése, hogy a külvilágból érkezett információkat az agyunk oly módon fogadja be, hogy azokat meglévő mentális mintákba illeszti bele, továbbá hogy ezek a meglévő mentális minták a korábban szerzett egyéni tapasztalatok függvényében végtelenül sokfélék lehetnek, és így mindenki agyában értelemszerüen más és más folyamatok zajlanak le akkor, amikor tanul. Ettől nem független a tanulás épitkezö jellegének a megértése, ami arra utal, hogy az agyunk a tudásunkat (megértésünket) nem lineáris módon építi fel, hanem úgy, hogy a már meglévő dolgokra épít rá újabbakat, és a további utat majd az fogja kijelölni, hogy milyen ,építményt” (mentális mintát) sikerült felépítenünk, vagyis mi az, amire a későbbiekben építhetünk. A tanulás innen nézve egyfajta fokozatos építkezés (scaffolding) az ismeretlen felé. Egy másik hasonló ered- 
mény az érzelmek és a motiváció meghatározó jelentőségének a felismerése. A bennünket érő információkat az agyunk nemcsak meglévő mentális mintákba „építi bele" vagy ilyenekhez kapcsolja hozzá, hanem ezeknek érzelmi jelentést is ad. A befogadásukat és a „beépítésüket” alapvetően meghatározzák érzelmi folyamataink, és érzelmi állapotunk drámai módon befolyásolja tanulási képességünket (például a szorongás nyilvánvalóan nagymértékben rontja azt). További eredmény a tanulás társas természetének a felismerése. Ez részben összefügg az érzelmekkel és a motivációval (a csoportfolyamatok meghatározzák érzelmeinket és motiváltságunkat), részben közvetlenül mentális folyamatokhoz kapcsolódik: a dolgok jelentésekkel való felruházása kollektív folyamat, a jelentés maga is csak társas térben, dialógusban, kommunikációban értelmezhető.

Mindezekkel és több más felismeréssel összhangban az egyik legfontosabb következtetés, amit a tanuláskutatás eredményei alapján meg kell fogalmaznunk az, hogy végtelen komplexitású jelenségről van szó. A tanulás végtelen komplexitásának - sokak szerint természeténél fogva kaotikus jellegének (Jörg, 2004) - a felismerése és elfogadása többek között azzal jár együtt, hogy bele kell nyugodnunk: ezt a folyamatot soha nem leszünk képesek teljes mértékben az ellenőrzésünk alatt tartani. A tanulók eredményes tanulását úgy kell megszerveznünk, hogy eközben nem tudhatjuk pontosan, hogyan is alakul az a folyamat, aminek a megszervezéséért felelösök vagyunk.

Mindezeknek a felismeréseknek a fényében - és itt érdemes hangsúlyozni, hogy ezek nem mindenki számára újak, de a tanuláskutatás most ezeket reflektorfénybe állította - sokan jutottak arra a következtetésre, hogy az iskolai tanulás megszervezésének az a módja, amely az iskolák történetileg kialakult formáját jellemzi, fenntarthatatlan. A tanulás természetéröl keletkezett új tudás további lökést adott azoknak a kezdeményezéseknek, amelyek célja az iskolai, osztálytermi folyamatok oly módon történő átalakítása, hogy azok jobban segítsék a tanulást, értve ez alatt természetesen annak második értelemben vett, itt autentikusnak nevezett formáját. Ha azonban reálisan gondolkodunk, és különösen akkor, ha figyelembe vesszük a tanulási folyamatok végtelen komplexitását, nehezen juthatunk más következtetésre, mint arra, hogy az osztálytermi szinten megközelíthetetlenek az oktatáspolitika számára. Paul Black és Dylan Wiliam, a londoni King's College két professzora, akik a kilencvenes évek végén több nagyhatású írást tettek közzé erről a dilemmáról, így írták le ezt:

„Rendszerszervezési szempontból a mai oktatáspolitika az osztálytermet fekete doboznak kezeli. Bizonyos inputokat megpróbálnak ide bejuttatni: követelményeket fogalmaznak meg a tanulókkal, a tanárokkal, az egyéb forrásokkal szemben, meghatározzák a szervezeti szabályokat, esetleg a szülöi aggódást próbálják felhasználni, vagy teszteket alkalmaznak és az ezeken elérendő eredményekre vonatkozó igényeket növelik, és egyéb módokon próbálkoznak. 
Ennek nyomán remélhetően megjelennek bizonyos outputok: így nagyobb tudással vagy fejlettebb kompetenciákkal rendelkező tanulók, jobb teszteredmények, többé vagy kevésbé elégedett vagy kevésbé kimerült tanárok. De mi történik a dobozban? Honnan tudhatjuk, vajon az inputok adott kombinációja jobb outputot eredményez-e, ha nem tudjuk, hogy belül mi történik?" (Black és Wiliam, 1998)

A tanulás jobbítását célzó oktatáspolitikák legnagyobb dilemmája az, vajon lehetséges-e a „fekete dobozban” zajló folyamatokat kívülről befolyásolni. Lehetséges-e olyan oktatáspolitikát megalkotni és megvalósítani, amely nemcsak „belelát” ebbe a dobozba, de „bele is tud nyúlni”, és az ott zajló folyamatokat valóban jobbá tudja tenni? A tanuláskutatás említett eredményei egyfelől reményt ébresztenek erre, másfelől, éppen a tanulás végtelen komplexitásának a bemutatásával gyakran lelohasztják az ezzel kapcsolatos reményeket.

A dilemma kezelését valamelyest enyhíti az, hogy ma már nemcsak a tanulás komplexitását látjuk, hanem a politikákét is, és különösen annak a folyamatnak a komplexitását, amelyet politika-implementációnak szoktunk nevezni. A kanadai Ontario Egyetem professzora, Benjamin Levin, aki egy ideig az egyik legsikeresebbnek tartott tanuláscentrikus oktatáspolitikát megvalósító minisztérium helyettes irányítója volt például ezt írta erről:

„....nem szabad a reformok esetében túlbecsülni az előremutató, egyenes vonalú racionalitás (straightforward rationality) jelentőségét. Általában nagymértékü ambivalenciával és kölcsönös függöségekkel (high level of ambiguity and contingency) szembesülünk a politikai folyamat minden területén. Minden egyes lépésnél sokféle és egymással konfliktusban lévő hatásokat kell elviselni, a célok változnak, vagy a létező struktúrák és folyamatok kiürítik őket, és a körülmények olyan módon alakulnak át, hogy módosítani kell a terveket és a tervezett lépéseket" (Levin, 2001).

A komplexitás számos oka közül az egyik az, hogy az oktatási rendszerek mind horizontálisan, mind vertikálisan olyan autonóm mozgástérrel bíró alrendszerekre oszlanak, amelyek egymással dinamikus interakcióba kerülnek, és általában nem lehet pontosan megjósolni, hogy ennek az interakciónak milyen kimenete lesz. Így például miközben a fejlett világ legtöbb oktatási rendszerében minden egyes iskola önálló világnak számít, amelyben a szervezeti és vezetési sajátosságok sokasága határozza meg azt, hogy a mennyire eredményes lesz a tanulás, ezek az iskolák ugyancsak önálló világoknak számító helyi rendszerekbe szerveződnek, amelyeknek szintén megvan a maga önmozgása. Finnországban például azokat a lokális tanterveket, amelyek alapján a tanítást megszervezik, sok helyen ezek a lokális (önkor- 
mányzati) irányítás alatt álló rendszerek alkotják meg. ${ }^{6}$ A tanuláscentrikus oktatáspolitikák számára az egyik legfontosabb kiindulási pont lett az egyszerre több szintben történő gondolkodás (intézményi, helyi és nemzeti), és annak végiggondolása, hogy az egyes szinteken minek kell történnie ahhoz, hogy az osztálytermi folyamatok változzanak. Michael Fullan, aki ugyancsak az Ontario Egyetem profeszszora volt, és akinek munkássága a tanulásközpontú oktatási reformoknak talán legnagyobb hatású szellemi bázisát alkotja, az egyik legfontosabb elvként fogalmazta meg a „háromszintü reformokban” (intézményi, helyi és nemzeti szintü változásokban) való egyidejü gondolkodás szükségességét (Fullan, 2008).

A tanuláscentrikus oktatáspolitikáknak általában fontos eleme az, amit curriculum-politikának szoktunk nevezni. A modern curriculum-gondolkodásnak is egyik legfontosabb jellemzője lett a többszintü gondolkodás. A holland nemzeti tantervkutató intézet, az SLO vezetője, a Twente-i Egyetem professzora, Jan van den Akker szerint például egyszerre öt szinten kell gondolkodnunk: az egyes tanuló, az osztály vagy tanuló csoport, az iskola vagy képzési program, az országos és a nemzetfeletti szintben $(A k k e r, 2005)$. Ez alapvető eltérés attól a gondolkodástól, amely egy évtizeddel ezelőtt még domináns volt, és amely összemosta az egyes szinteken eltérő módon kezelendő problémákat. ${ }^{7}$ Abban, hogy önálló curriculum-elméleti szintként jelenik maga az egyes tanuló (Akker ,nano-szintnek” mondja ezt) a tanulástudomány korábban idézett hatását is érzékelhetjük.

A fentiekkel kapcsolatban érdemes különösen erősen hangsúlyozni: a többszintü és bonyolult belső dinamikával rendelkező rendszerek logikájának a felismerése és az ehhez történő alkalmazkodás nélkül a tanuláskutatás eredményei nem vihetőek át oktatáspolitikai szintre. Másképpen fogalmazva: mindabból, amit az emberi tanulásról tudunk, nem lehet közvetlenül és lineáris módon következtetéseket levonni arra nézve, hogy az oktatás nemzeti szintủ szabályozásában mit kellene tenni. Azok az implicit sémák, amelyekkel a tanuláskutatók nem ritkán rendelkeznek az oktatási rendszerek müködéséröl, hajlamossá teszik őket arra, hogy elhamarkodott oktatáspolitikai következtetéseket vonjanak le, túlbecsülve például a nemzeti szintü tantervek befolyását a tanári viselkedésre vagy az iskolák müködésére. Arra van szükség, hogy az egyénekben zajló folyamatokra fókuszáló tanuláskutatók az oktatási rendszerek müködésben is meglássák ugyanazt a komplexitást, amit az emberi tanulás világában megláttak, és amit, mint láthattuk, azok a gyakorlati oktatásfejlesztéssel vagy curriculum-politikával foglalkozó szakemberek, akik folyamatosan a tanuláskutatás és a gyakorlat közötti hidakon közlekednek, helyzetükböl fakadóan könnyebben meglátnak.

\footnotetext{
${ }^{6}$ Beszéltem olyam finn városi oktatásügyi vezetőkkel, akik a helyi tantervkészítési folyamatot koordinálták és olyan iskolaigazgatókkal, akik ebben részt vettek.

${ }^{7}$ Érdemes megemlíteni, hogy a hazai közoktatási decentralizációval együtt a haza tantervelméleti gondolkodás is átvette a többszintü gondolkodást, aminek többféle megnyilvánulása is megfigyelhető (Perjés és Vass, 2008).
} 


\section{A tanuláscentrikus oktatáspolitikák jellemzői}

Az előző részben már több ponton érintettem azokat az elemeket, amelyek a tanuláscentrikus oktatáspolitikákat jellemzik, és amelyekben gyakran megragadható a tanulástudomány vagy tanuláskutatás által létrehozott eredmények hatása. Az ilyen politikák egyik legfontosabb jellemzője a minden egyes tanulóra történö odafigyelés, vagyis annak a követelménynek a megfogalmazása, hogy kivétel nélkül minden tanuló képességfejlődését nyomon kell követni, és kivétel nélkül minden olyan esetben be kell avatkozni, amikor problémák jelentkeznek. Ez együtt jár olyan rendszerek és olyan mechanizmusok kifejlesztésével, amelyek lehetővé teszik minden egyes tanuló fejlődésének a szoros nyomon követését, és nem engedik meg azt, hogy „selejtek” keletkezzenek, azaz egyesek lemaradhassanak és kiessenek a tanulási folyamatból. E folyamat mind rendszerszinten, mind intézményi szinten zajlik (Halász, 2008a).

Nemzeti szinten ez olyan politikákban ölthet testet, mint amilyen például a 2001-ben elfogadott amerikai „,No Child Left Behind” (,Egyetlen gyereket sem hagyunk magunk mögött") törvényben ${ }^{8}$ jelent meg, vagy amelyet az angol kormány 2003-ban „Every child matters” („Minden gyerek számít”) címü stratégiája ${ }^{9}$ fogalmazott meg. Ezek közös vonása az, hogy olyan mechanizmusokat próbálnak meg létrehozni, amelyektől azt remélik, garantálni tudják a „selejt” nélküli működést. Ezeknek - a korábbiakban mondottakkal összhangban - két kulcselemét érdemes itt kiemelni: az egyik olyan tesztelö rendszerek létrehozása és müködtetése, amelyek minden egyes iskola és minden egyes gyerek tanulási eredményeit folyamatosan értékelik; a másik, olyan intézkedések, amelyek kikényszerítik a korai beavatkozást minden olyan esetben, amikor a teszteredmények azt jelzik, hogy problémák vannak. Ennek egyik jellegzetes példáját éppen az említett amerikai „No Child Left Behind" (NCLB) törvény teremtette meg:

„A ,No Child Left Behind’ törvény hatálya alatt az államok azon dolgoznak, hogy megszüntessék a tanulmányi teljesítményekben mutatkozó szakadékokat és garantálják azt, hogy minden egyes tanuló, beleértve ebbe a hátrányos helyzetűeket is, megfelelő tanulmányi teljesítményt (academic proficiency) érjen el. Éves állami és iskolakörzeti jelentésekkel kell informálni a szülöket és a közösségeket az állam és az iskolák előrehaladásáról. Azoknak az iskoláknak, amelyek elörehaladása nem megfelelö, különleges támogatást kell nyújtani, mint amilyen az ingyenes különórák vagy a tanórán kívüli támogatás. Az ilyen iskolák esetében korrekciós intézkedéseket kell hozni, és ha öt éven belül ezek hatására sem történik elörehaladás, radikális módon meg kell változtatni (make dramatic changes) azt a módot, ahogyan müködnek" (US Department of Education, 2004).

\footnotetext{
${ }^{8}$ Lásd: http://www.ed.gov/nclb/landing.jhtml?src=ln

${ }^{9}$ Lásd: http://www.everychildmatters.gov.uk/aims/background/
} 
Iskolai szinten ez hasonló mechanizmusok müködtetését jelenti. Az iskoláktól azt várják el, hogy olyan belső tanulásmenedzsment rendszereket müködtessenek, amelyek lehetővé teszik a tanulók előrehaladásának egyéni szintü nyomon követését, és egyúttal olyan belső szervezeti és munkaszervezési formákat hozzanak létre, amelyek egyfelől kikényszerítik a reagálást minden olyan esetben, amikor a nyomon követő rendszerek problémát jeleznek, másfelől segítik annak a pedagógiai problémamegoldó képességnek a folyamatos fejlesztését, amelyre szükség van a sikeres beavatkozás érdekében.

Mindez tulajdonképpen egyfajta többszintü és teljes körünek gondolt minöségbiztositási rendszerként müködik, amely megpróbálja kizárni vagy a minimálisra csökkenteni a tanulási kudarcok szőnyeg alá söprésének a kockázatát. Rögtön hozzá kell azonban ehhez tenni, hogy az ilyen oktatási stratégiákat rendkívül erős kritika éri, mégpedig a gyakran éppen az autentikus tanulás mellett elkötelezettek részéről. Az ilyen stratégiák ugyanis - bár kétségtelenül komolyan veszik azt, hogy tényleges és ne csak látszattanulás történjen - a tanulás eredményességét gyakran rendkívül szüken értelmezik, emellett olyan kontroll-rendszereket hoznak létre, amelyek bürokratizálják a tanulásszervezést, és látszateredmények produkálására késztetik az iskolákat. A tanulási eredmények mérhetőségéhez való ragaszkodás miatt a figyelem szinte kizárólag a tanulás könnyen mérhető eredményeire fókuszálódhat, ami nem elősegíti, hanem rontja az összetett, magasabb rendủ képességek fejlesztésének az esélyeit. E paradox hatás miatt érik az amerikai NCLB politikát a legkülönbözőbb szintekröl néha megsemmisítö bírálatok.

A korábban már említett Richard Elmore például, arra hívja fel a figyelmet, hogy az iskoláknak, amelyek megpróbálnak alkalmazkodni a szigorú kimeneti követelményekhez, gyakran fogalmunk sincs arról, konkrétan mit kellene csinálniuk annak érdekében, hogy megfeleljenek ezeknek a követelményeknek, és így az eröfeszítéseik középpontjába nem a tanulás tényleges jobbá tétele kerül, hanem látszateredmények produkálása (Elmore, 2008). Elmore, másokkal együtt, azt hangsúlyozza, hogy a tanulás eredményesebbé tételére a külső elszámoltatatást (accountability) hangsúlyozó politikák nemcsak, hogy nem alkalmasak, hanem egyenesen ellentétes hatást váltanak ki. Ahhoz, hogy az iskolák képessé váljanak a tanulás eredményesebbé tételére, az kell, hogy a ,,lebutított” külső elszámoltatás helyébe az intelligens belső elszámoltatás lépjen. Ez utóbbi olyan vezetést és belső szervezeti viszonyokat igényel, amelyek az iskolákat olyan intelligens tanulószervezetté alakítják, amelyek képesek megérteni a tanulás komplex jellegét és nemcsak képesek, de motiváltak is arra, hogy olyan tanulási környezetet hozzanak létre, amely kedvez az autentikus tanulásnak.

Mindez jól mutatja, mennyire bonyolult - sokak szerint szinte reménytelen feladattal szembesül minden olyan oktatáspolitika, amely komolyan veszi a tanulást, és azt a célt, hogy az iskolákban valóban autentikus tanulás folyjék. Az ilyen oktatáspolitikákra éppen azok a csapdák leselkednek, amelyeket a NCLB törvény- 
ben testet öltő politika nem vagy alig tudott elkerülni. Az ilyen politikák általában jó irányba indulnak el akkor, amikor a hangsúlyt az eredményekre helyezik, és ezeket az eredményeket kompetenciákban vagy tanulási kimenetekben (learning outcomes) próbálják meghatározni, majd standardokat állítanak fel és az eredményeket e standardokkal próbálják összevetni. A megvalósulás során azonban a leggyakrabban kiderült, hogy a magasabb szintü képességek (kompetenciák, tanulási kimenetek) standardizálhatóságának komoly korlátjai vannak, hiszen ezek végtelenül komplex természetüek. Az autentikus tanulás és az ennek eredményeképpen kialakuló komplex képességek standardizálására való törekvés nemegyszer pedagógiai tekintetben első látásra rendkívül impozáns, de a gyakorlatban teljesen müködésképtelen mechanizmusokat hoz létre.

Érdemes felidézni ennek egyik, a közelmúltban ismertté vált jellegzetes példáját a Dél-Afrikai képesítési rendszer reformját, ahol a legprogresszívabb kompetencia-alapú modelleket követve hoztak létre egy olyan rendszert, amely végtelen alapossággal próbálta leírni a bonyolult képességeket és ezek összetevőit, azonban ennek eredményeképpen olyan áttekinthetetlen leírást produkált, amiben alig valaki tudott eligazodni, és amely - ahogy ezt a gyakorlat közvetlenül igazolta - nem vált alkalmassá a pedagógiai gyakorlat tényleges orientálására. E reform kudarcának egyik különösen éles látású Dél-Afrikai elemzője Stephanie M. Allais, éppen a komplexitás túl magas szintjét és az ennek a kezelésére való képtelenséget jelöli meg a kimenet alapú (outcome based) reformok legnagyobb kockázataként (Allais, 2007). A tanulási kimenetek vagy fejlesztendő kompetenciák legteljesebb körü leírására törekvés egyfajta „specifikációs spirált” indíthat el, aminek eredményeképpen a lehető legnagyobb világosságra való törekvés végül a lehető legátláthatatlanabb dolgokhoz vezet (lásd a keretes irást).

Visszatérve a tanulási eredmények méréséhez és nyomon követéséhez: azok az országok, amelyek oktatáspolitikai prioritássá tették a tanulás eredményesebbé tételét, e politika egyik sarokköveként kezelik a mérési és értékelési rendszer reformját. Abból kiindulva, hogy e rendszerek által adott visszajelzések alapvetően befolyásolják az iskolák és a pedagógusok viselkedését, a rendszerek olyan átalakítására törekszenek, hogy azok garantáltan az autentikus tanulás számára releváns visszajelzéseket nyújtsák. E területen az egyik leggyakrabban idézett és leggyakrabban követett minta az, amelyet az elmúlt években a skóciai oktatáspolitika hozott létre: egy olyan rendkívül szerteágazó programról van szó, amelynek célját jól mutatja az elnevezése: „Az értékelés a tanulást szolgálja”. ${ }^{10}$ E programnak három pillére van: az első a „Értékelés a tanulásért”, amely azt fejezi ki, hogy az értékelésnek bele kell épülnie a tanulásszervezés mindennapos tevékenységébe, folyamatosan orientálnia kell azt, és annak a céljait kell szolgálnia. A második „, $A z$

\footnotetext{
${ }^{10}$ A program angol neve „Assessment is for learning” (AifL). A program weblapját lásd itt: http://www.ltscotland.org.uk/assess/index.asp.
} 
értékelés, mint tanulás", ami arra utal, hogy az értékelés része magának a tanulási folyamatnak és segíti a tanulás megtanulását. A harmadik „A tanulás értékelése”, ami az értékelés leginkább megszokott és leginkább ismert jelentésére utal. ${ }^{11} \mathrm{Ez}$ a nagyhatású program azt igazolja, hogy kellő politikai elhatározás esetén lehetséges összhangot teremteni az autentikus tanulás eredményességét támogató oktatáspolitikai törekvések és a tanulás megszervezésére legnagyobb hatással bíró intézményi és szabályozó folyamatok, ezen belül az értékelés között.

„A kimeneteknek (outcomes) transzparensnek és ambivalenciamentesnek kell lenniük annak érdekében, hogy az értékelők ugyanolyan módon értékeljék, a különböző emberek hasonló módon interpretálják öket, és ennél fogva hordozni tudják a standardokat. Azoknak is meg kell érteniük az adott kompetenciák fejlesztését szolgáló képzési programokat és azt, hogy a képzés eredményeit miként értékelik, akik nem rendelkeznek szakértői szintü tudással (így a tanulóknak, a szülőknek és másoknak, akik kívül vannak az intézményeken és a tanult szakmákon). A tanulási kimenetek leírása azonban soha nem eléggé transzparens ahhoz, hogy úgy jelenítsenek meg kompetenciákat, hogy azok mindenki számára ugyanazt jelentsék. Ezért mindig újabb és újabb specifikációkra van szükség. (...) A tudás ebben a kontextusban apró információmennyiségekké válik. Más szavakkal a specifikációk komplex spirálja nem kapcsolódik tudásterületekhez. Annak erőltetése, hogy a tudást a tanulási kimeneteket leíró állításokból (outcome statements) vezessék le és ilyenekhez viszonyítva értékeljék, trivializálja és összefüggéstelen információdarabokká aprózza a tudást" (Allais, 2007, 532. o. és 537. o.).

\section{Behatolás a „fekete dobozba”}

A tanulást és annak eredményességét komolyan vevő tanuláscentrikus oktatáspolitikáknak valószínüleg két nagyobb modelljét lehet és érdemes megkülönböztetni. Az egyik lemond arról, hogy behatoljon a „fekete dobozba”, és elsősorban a külső standardok megfogalmazásán, az ezekre épülő külső értékelésen és - sok esetben az értékelés nyomán alkalmazott szankciókon vagy éppen fejlesztő beavatkozásokon alapszik. A másik számára viszont éppen az érdekes, ami a „fekete dobozban” történik, és megpróbál behatolni abba a végtelenül komplex világba, amit a tanulás és a tanulás szervezése jelent.

\footnotetext{
${ }^{11}$ A három pillér angol elnevezése „Assessment FOR learning”, „Assessment AS learning” és „,Assessment OF learning”. A magyar nyelv sajnos nem érzékeny az ,assessment” és az „,evaluation” fogalmak közötti különbségre, így itt mindkettőt az „értékelés” szóval jelöljük. Az értékelés és a tanulás kapcsolatáról lásd még Rapos Nóra tanulmányát e kötetben.
} 
Az elöbbi modell, a gyakran kimenet alapúnak (outcome based) mondott oktatáspolitika hívei legalább két csoportra oszthatóak: vannak olyanok, akik tisztában vannak a tanulás természetével, és éppen ezért tekintik illúziónak azt, hogy az állami politika ebbe a végtelenül komplex világba eredményesen behatolhasson. Ök is a felszínen maradnak, de nem azért, mert nem gondolnák fontosnak a mélyben zajló folyamatokat, hanem azért, mert túlságosan jól ismerik azt, és ezért nem hiszik, hogy oda „le lehet menni”. A másik oldalon azok vannak, akiknek a tanulás természetéről egyáltalán nincs elképzelésük, vagy legfeljebb elavult és leegyszerüsítő sémákkal rendelkeznek erről. Az utóbbiakra itt nem érdemes sok szót vesztegetni, az elöbbiek viszont mindenképpen számot tarthatnak a figyelmünkre. A tanulás természetének az a fajta megértése ugyanis, amelyet többek között a modern tanuláskutatás eredményei tettek lehetővé a számunkra, valóban kétféle oktatáspolitikai gondolkodás felé vihet el bennünket.

Juthatunk arra a következtetésre is, hogy a tanulással való komoly foglalkozást rá kell bízni az iskolákra és a tanárokra, mert kívülről úgysem tudja senki megmondani azt, hogy mit kell tenniük. Ebben az esetben a tanárokat olyan szakértőknek tekintik, akiknek a tanult tudásuk és képességeik alapján maguknak kell kreatív módon kitalálniuk, hogyan szervezzék meg a tanulást a legeredményesebb módon. Ebben persze korlátozzák őket a különböző szakmai standardok és protokollok, és használniuk kell olyan készen adott „,technológiákat”, amelyekhez standard használati módok társulnak (például oktatási programcsomagokat). Ennek ellenére, alapjában véve rajtuk múlik, hogyan szervezik meg a tanulást. Az államnak ebben az esetben csupán annyi a feladata, hogy a külső értékelés eszközeivel minimálisra csökkentse azoknak az eseteknek a kockázatát, amikor a tanárok nem a tanulás jobbítására használják a szaktudásukat, hanem például vallási vagy ideológiai indoktrinációra, vagy esetleg a végzettségeket igazoló dokumentumok nem korrekt módon történő terjesztésére. E mellett az állam annyit tehet még, ha erre van elég erőforrása, hogy olyan fejlesztő tevékenységekbe invesztál, amelyeknek az eredményeként különböző standard módon használható és minőségbiztosított eszközök (például jól bevált oktatási programcsomagok) keletkeznek, valamint ezeknek széles körü kínálata áll a tanárok rendelkezésére, továbbá támogatja a tanárokat és az iskolákat ezek beszerzésében és használatuk megtanulásában.

A tanulás természetének a megértése és a tanulás komolyan vétele melletti elkötelezettség azonban egészen másfajta oktatáspolitikai következtetések levonását is eredményezteti. Ez abból indul ki, hogy a tanulás megértése és a tanulás komolyan vétele olyan nagyságú kihívást jelent az iskolák és a tanárok számára, hogy saját erejükből csak kevesen lesznek képesek ennek megfelelni. A komplex képességek vagy kompetenciák fejlesztése nem tervezhető ugyanolyan módon, ahogyan korábban a megtanítandó tananyagot rögzítő tanterveket alkották meg. Ebben az esetben olyan tanulási helyzetek megteremtéséről kell gondoskodni, amelyektől azt várjuk, hogy - a tanuláskutató Cowan korábban idézett szavaival - a motivált tanu- 
lók ne tudjanak úgy kijutni, hogy ne tanuljanak. Az ilyen tanulási helyzetek létrehozása is tervezést igényel, sőt sokkal komolyabbat és mélyebbet, mint amilyet a megtanítandó tananyagot rögzítő korábbi tantervek tervezése. Ez a tervezés két alapvető szempontból eltér a megszokott mintától: itt ugyanis a tervezés elsősorban mikro-szinten, azaz az egyes iskola, az egyes osztályterem, az egyes képzési program vagy kurzus szintjén történik, és - ami legalább ilyen fontos - a tervezésnek meghatározó eleme a folyamatos önkorrekció, a visszajelzések alapján történő folyamatos újratervezés. Azok az iskolák, amelyek több évszázadon keresztül úgy müködtek, és azok a tanárok, akiket úgy szocializáltak, hogy kövessék a központilag meghatározott programok merev szabályait, önmaguktól nem képesek átállni ennek az új modellnek a követésére.

Azok az országok, amelyek különböző okokból - az esetek jelentős részében azért, mert a gazdaság kulcsszereplöi, ahogy ezt e tanulmány elején próbáltam hangsúlyozni, elkezdtek hinni abban, hogy a versenyképességüket ez szolgálja elköteleződtek a tanuláscentrikus oktatáspolitika mellett, általában nem állnak meg a kompetencia-standardok megfogalmazásánál és az ehhez kapcsolódó értékelésimérési rendszerek kiépítésénél. Ehelyett további lépéseket tesznek előre, és megpróbálják az iskolák pedagógiai kultúráját megújítani annak érdekében, hogy megvalósulhasson a tanulás intelligens iskolai szintủ tervezése. E folyamatnak legalább két alapvető eleme van: az egyik magának a pedagógiai gondolkodásnak, éppen a tanuláskutatás eredményeire és a tanuláskutatásból szerzett evidenciákra épülö megújítása, a másik az iskola, mint szervezet alkalmassá tétele arra, hogy ezt a pedagógiai gondolkodást befogadja és a müködését ennek megfelelően tudja megszervezni.

Annak, hogy a pedagógiai gondolkodásnak a tanuláskutatás által létrehozott evidenciákra épülö megújítását milyen eszközökkel segítheti az oktatáspolitika, egyik figyelemre méltó példája a 2000-ben elindult angliai Tanitás- és Tanuláskutatás Program, amely az ország történetének talán legnagyobb oktatáskutatási befektetése. ${ }^{12}$ A program egyik legfontosabb jellemzője az, hogy bár sok szempontból klasszikus kutatási projekteket támogat, elsődleges célként mégsem a tudományos ismeretek mennyiségének a növelését tüzte ki, hanem a tanuláskutatás eredményeinek az iskolai és oktatáspolitikai gyakorlatba történő bevitelét, a kutatók, az oktatáspolitika és az iskolák közötti „hidak” építését (Pollard, 2007). A program egyik terméke néhány ún. ,pedagógiai elv” megfogalmazása, ami részben a tanuláskutatás által létrehozott evidenciákra, részben a tanuláskutatók és az iskolák közötti konzultációkra épül, és amit a program egyik legfontosabb eredményeként tartanak számon (lásd a keretes irást).

122006 öszén a program költségvetése 37 millió angol font volt (Pollard, 2007). A program (Teaching and Learning Research Programme) honlapját lásd: http://www.tlrp.org/index.html. 


\section{Az eredményes pedagógia tíz alapelve \\ (az angol Tanítás- és Tanuláskutatás Program következtetései)}

- Az eredményes pedagógia a legtágabb értelemben készíti fel a tanulókat az életre.

- Az eredményes pedagógia a tudás értékes formáit viszi a tanulókhoz.

- Az eredményes pedagógia felismeri a korábban megszerzett tapasztalatok és az előzetes tanulás fontosságát.

- Az eredményes pedagógia a tanulás fokozatosan építkező jellegére (scaffolding) épül.

- Az eredményes pedagógiának olyan értékelésre van szüksége, amely összhangban van a tanulással.

- Az eredményes pedagógia elősegíti a tanuló aktív elkötelezettségét.

- Az eredményes pedagógia egyaránt támogatja az egyéni és a társas folyamatokat, valamint kimeneteket.

- Az eredményes pedagógia felismeri az informális tanulás fontosságát.

- Az eredményes pedagógia szükségesé teszi azoknak a tanulását is, aki mások tanulásának a megszervezésért felelnek.

- Az eredményes pedagógiának olyan politikai környezetre (policy framework) van szüksége, amely a tanulást helyezi a középpontba.

Forrás: TLRP, 2008

Ezek a pedagógiai elvek lényegében a tanulásszervezés ma eredményesnek tartott módszereit írják le (témánk szempontjából figyelemre méltó, hogy az egyik alapelv éppen az, hogy a politikai környezetre a tanuláscentrikus oktatáspolitika jelenléte legyen jellemző). Hasonló elvek több országban is megfogalmazódnak, nemegyszer a nemzeti tartalmi szabályozási dokumentumokba beleépülve. Így például az ÚjZéland nemzeti alaptanterve a fejlesztendő kompetenciák mellett részletesen bemutatja azokat a pedagógiai elveket és módszereket is, amelyek a tanuláskutatás korábban ismertetett eredményeire épülnek, és amelyeket a sikeres kompetenciafejlesztéshez szükségesnek tart. Ezek: (1) a támogató pedagógiai környezet kialakítása, (2) a reflektív gondolkodás és cselekvés bátorítása, (3) az új dolgok tanulása esetén azok relevanciájának hangsúlyozása, (4) a társakkal történő közös tanulás, (5) a korábbi tanuláshoz és tapasztalatokhoz való hozzákapcsolás, (6) a kellö mennyiségü és változatos tanulási alkalom felkínálása és végül (7) a tanítás tanulásként történő értelmezése. Az Új-Zéland-i nemzeti tantervi dokumentum külön kiemeli azt, hogy „,mivel különbözö kontextusokban minden tanitási stratégia másképp müködik, az eredményes pedagógia megkívánja azt, hogy a tanárok folyamatosan elemezzék azt, hogy a tanitási gyakorlat milyen hatással van a tanulókra" (Ministry of Education, 2007). 


\section{A vezetési és szervezeti dimenzió felértékelódése}

Említettem, hogy azok az országok, amelyek elkötelezték magukat a tanuláscentrikus oktatáspolitika mellett, megpróbálják megújítani az iskolák pedagógiai kultúráját és az iskolákat intelligens tanuló szervezetekké próbálják alakítani. Ez nélkülözhetetlenné teszi az iskolavezetés megújítását, így ezekben az országokban a vezetésfejlesztés, tágabban a szervezetfejlesztés az oktatáspolitika egyik kiemelt prioritásává válik.

Annak a felismerése, hogy a vezetés minősége nagymértékben befolyásolhatja a tanulás minőségét nem új, de azok az evidenciák, amelyek ezt komolyan alátámasztják, csupán az elmúlt egy-másfél évtizedben születtek meg. E tanulmány írásának idején is zajlik számos olyan kutatás, amely a vezetés minősége és a tanulás eredményessége közötti kapcsolatok természetét vizsgálja, és amelyek nyomán újabb oktatáspolitikai és oktatásfejlesztési ajánlások megfogalmazása várható. Itt négy olyan kutatást emelek ki, amelyeknek különösen nagy hatása volt, vagy nagy hatása várható, és amelyek a témánk szempontjából is különösen figyelemre méltónak tủnnek

Az első kettő olyan metaelemzés, amely mások korábban elvégett kutatásainak eredményeit tekinti át. Az egyiket ezek közül két amerikai kutató, Philip Hallinger és Ronald Heck tette közzé egy, 1998-ban megjelent, azóta igen sokszor idézett publikációjukban (Hallinger és Heck, 1998). Ebben áttekintették az összes olyan korábbi empirikus kutatást, amelyek a vezetés jellemzői és a tanulás eredményességei közötti kapcsolatot próbálták feltárni, arra keresve a választ, hogy bár a józan ész alapján azt gondoljuk, ennek a kapcsolatnak erősnek kell lennie, a konkrét kutatások jelentős része ezt mégsem tudta kimutatni. Azt állapították meg, hogy ennek egyszerüen az az oka, hogy a legtöbb kutatás hibás elméleti modellből indult ki, figyelmen kívül hagyva azt, hogy ez a kapcsolat nem direkt módon hat, hanem közvetítéseken keresztül. A vezetés minősége a szervezet bizonyos jellemzőit befolyásolja, és a tanulás eredményességére ezek a szervezeti jellemzők vannak hatással. Továbbá a vezetésnek nem azok a jól mérhető és közvetlenül látható jellemzői számítanak, mint például a vezetők neme, életkora, iskolázottsága és hasonlók, amelyekre a kutatók a leggyakrabban koncentrálnak, hanem olyan attitüdbeli és viselkedésbeli jellemzők, amelyeket a kérdőíves adatgyüjtések nem vagy csak nehezen tudnak megragadni.

A másik metaelemzés szerzője 26 korábbi (1978 és 2006 között végzett) kutatás tapasztalatait foglalta össze, és ennek alapján öt olyan vezetési dimenziót emelt ki, amelyek mérhető és szignifikáns kapcsolatban állnak a tanulás eredményességével. Ezek a következők: (1) a célok és elvárások megfelelő megfogalmazása, (2) az ezeknek megfelelő stratégiai forrás-allokálás, (3) a tanítás és a kurrikulum tervezésének, koordinálásának és értékelésének adekvát módja, (4) a tanárok tanulásá- 
ban és fejlödésében való aktív részvétel, valamint (5) a rendezett és támogató környezet fenntartása (Robinson, 2007).

A harmadik olyan kutatás, amelyet érdemesnek tünik kiemelni, az elmúlt években az egyik legnagyobb hatásúnak bizonyult. Az ausztráliai Bill Mulford irányította, aki az University of Tasmania ,Vezetés a tanulásért kutatócsoportjának” vezetője. E kutatás keretében kilencven iskolában követték nyomon azt, hogy a tanulószervezet létrehozását szorgalmazó iskolavezetés milyen hatással van a tanulók teljesítményére, beleértve ebbe a standardizált tesztekkel nehezen mérhető elemeket is (Mulford és Silins, 2003). E különleges módszertani alapossággal megtervezett és igen összetett modellt alkalmazó kutatás világos összefüggést mutatott ki a vezetés minősége és a tanulás eredményessége között. A kiinduló hipotézis, ami a kutatás nevében is megfogalmazódott, ${ }^{13}$ eleve indirekt hatásrendszerrel kalkulált: a vezetés azzal képes javítani a tanulás eredményességét, ha megteremti a szervezeti tanulás feltételeit, azaz az iskolát olyan intelligens tanulószervezetté alakítja, amelynek megnő a tanulás szervezésével összefüggő komplex problémamegoldó képessége.

Végül a negyedik kutatás egy olyan kutatássorozat része, amelyet az amerikai Wallace alapitvány finanszírozott több éven keresztül, és amelynek első eredményei 2008-ban jelentek meg. Ennek vezetöi Karen Seashore, a Minnesotai Egyetem, és Kenneth Leithwood, a Torontoi Egyetem tanárai, akik mindketten a tanuláscentrikus-vezetés ismert kutatói. Seashore több mint 4000, különböző amerikai államokban dolgozó tanár adatainak a feldolgozása nyomán erösíthette meg azt, hogy a tanárok által alkalmazott tanulásszervezési módszerek minőségét egy időben határozzák meg személyes kvalitásaik és az a szervezeti-vezetési környezet, amelyben dolgoznak (Seashore és Wahlstrom, 2008). Ez utóbbinak két alapvető dimenzióját elemezték: az egyik a vezetők és a tanárok közötti kapcsolatok jellege (ezen belül a bizalom és a vezetési funkciókba történő bevonás mértéke), a másik a tanárok közötti kapcsolatok (ezen belül a szakmai közösség megléte és a közös felelösség). A szervezeti-vezetési környezet persze jóval összetettebb annál, hogysem leírható legyen néhány változóval. Ezért is használták szívesen a szervezeti kultúra vagy a szervezeti klíma fogalmait.

Noha a fentiek közül különösen Mulford kutatása helyezett nagy hangsúlyt a szervezeten belüli tanulásra vagy a szervezeti tanulásra, mindegyik azt erősítette meg, hogy azok az iskolák képesek a tanulás eredményes megszervezésére, amelyekben a tanárok olyan szakmai közösséget alkotnak, amely intenzív és folyamatosan szakmai kommunikációt tart fenn. Az ilyen iskolákra olyan vezetés és olyan szervezeti kultúra vagy szervezeti légkör jellemzö, amely támogatja azt a fajta szakmai kommunikációt, amely lehetővé teszi a folyamatos egymástól történő tanulást és a komplex pedagógiai dilemmák kollektív megoldását. Az ilyen iskolákban ki tudnak alakulni azok a problémaközösségek vagy gyakorlatközösségek, amelyek lehetővé teszik

\footnotetext{
${ }^{13}$ A kutatás elnevezése „Leadership for Organisational Learning and Student Outcomes (LOLSO)”.
} 
annak a pedagógiai tudásnak a megosztását, amelyet nehezen vagy nem lehet teljesen explicitté tenni, és amelynek a minősége alapvetően meghatározza azt, hogy egy-egy iskolában a tanulásszervezés milyen technikái alakulhatnak ki.

Számos olyan elemző van, aki a kelet-ázsiai országok kiemelkedő oktatási teljesítményét éppen arra vezeti vissza, hogy ezekben az országokban hagyományosan létezik a tudásmegosztásnak és a kölcsönös tanulásnak az a kultúrája, amely lehetővé a tanulásszervezés technológiájának folyamatos és intelligens mikroszintü fejlesztését. A japán iskolákra jellemző kollektív tanóraelemzés, amit Gordon Györi János „tanórakutatásnak” nevez (Gordon Györi, 2007) éppen ezt a funkciót tölti be. Ferenc Marton, a Göteborgi Egyetem professzora így írta le ezt:

„Japánban az azonos tantárgyat tanító pedagógusok 6-8 fös „lesson study” csoportokat alkotnak, amelyekben iskolán kívül tevékenykedő szakemberek (kutatók, pedagógusképzők) is részt vesznek. A csoport félévente egyszer ülésezik, ekkor kidolgoz egy „lesson study”-t. Ennek keretében kiválasztanak egy olyan lényeges tanulási tárgyat, melynek elsajátítása korábban nehézséget jelentett a tanulók számára. A munka folyamán a csoport saját tapasztalataira, illetve a releváns kutatási eredményekre támaszkodik. A résztvevők közösen megterveznek egy tanórát, amely elgondolásuk szerint a lehető leghatékonyabb módon fogja segíteni a kérdéses tanulási tárgy elsajátítását. Ezután kiválasztanak maguk közül valakit, aki kipróbálja, azaz a kidolgozott óraterv szerint megtartja az órát, míg a többiek ülnek és figyelnek. A tanórát megbeszélés követi, melyben a csoport értékeli a látottakat, és megnevezi a tanóra erős, illetve gyenge pontjait. A csoport ezután újabb óratervet dolgoz ki, amit már egy másik pedagógus próbál ki. A többiek ezúttal is ülnek és figyelnek. A második tanórát szintén megbeszélés követi, a tanulmány során szerzett tapasztalatokat a résztvevők összegzik és dokumentálják. A japán tanárok számára minden egyes dokumentált „lesson study” egyfajta kollektív emlék-anyagként szolgál" (Marton, 2004, 389. o.).

Érdemes felfigyelni arra, hogy a japán példában „iskolán kívül tevékenykedő szakemberek" is megjelennek. A japán pedagógus-foglalkoztatási rendszernek és a pedagógusok szakmai fejlesztésének egyik meghatározó eleme a tanárok iskolák közötti mozgásának a támogatása (Gordon Györi, 2002). Az eredményes tanuláscentrikus oktatáspolitikát folytató országokban szinte mindenütt különös figyelmet fordítanak arra is, hogy ez a szervezeti és vezetési kultúra ne csak az egyes iskolák belső viszonyait jellemezze, hanem az iskolaközi kapcsolatokat is, mivel a kölcsönös egymástól történő tanulásnak egy-egy iskola túlságosan szük keretét alkotja. A gyakorlatközösségek iskolákon átívelő szerveződését számos országban olyan tudatos politikák támogatják, amelyek mellé jelentős forrásokat is társítanak. Angliában például van olyan program, amely azt próbálja elérni, hogy az intézményi vezetők 
egy része ún. rendszerszintü vezetési funkciókat (systemic leadership) vállaljon, és az iskolák közötti tudás- és tapasztalat-megosztás hordozója legyen. ${ }^{14}$ Az egyes iskolákon átívelő szakmai hálózatok tudatos fejlesztésével részben azt próbálják elérni, hogy egyetlen iskola se maradhasson ki annak a kollektív pedagógiai tudásnak a megosztásából, amelynek a terjesztésére a hagyományos képzési és pedagógustovábbképzési rendszerek sok okból nem lehetnek képesek, és részben ebben látják a tanulás és tanítás folyamatos jobbításához nélkülözhetetlen innovációk keletkezésének és elterjedésének a lehetőségét (Sliwka, 2005).

Angliát már többször idéztem, mint az egyik olyan országot, ahol a nemzeti oktatáspolitika a vezetés fejlesztését a legkövetkezetesebb módon a tanulás fejlesztésének a szolgálatába állítja. Ennek egyik leginkább látható megnyilvánulása a Nemzeti Iskolavezetési Iskola (National School for School Leadership) létrehozása volt 2002-ben (e lépés politikai súlyát jelezte, hogy az intézményt az akkori kormányfö, Tony Blair avatta fel). Az iskola négy alapcélja közül az első a gyerekek tanulási teljesítményének és jólétének jobbítása kiváló iskolavezetés révén. ${ }^{15}$

Érdemes még megemlíteni egy másik olyan országot, ahol ma is a tanulás hagyományos értelmezése és a tanulásszervezés korábban iskolásnak nevezett (a tanuláskutatás előzőekben említett eredményei által kevéssé befolyásolt) módja uralkodik, és ahol egy váratlanul radikális modernizációs célokat kitüző, de mégis óvatos oktatáspolitika az elmúlt években a vezetés fejlesztését jelölte meg olyan eszközként, amely ezen változtathat. Az, hogy nem a jog kényszerítő eszközével viszik előre a reformokat, nemcsak az óvatosságnak, de a politikai ügyességnek is jele (és talán emellett még a szükséges források előteremtésére való képességnek is). Az osztrák szövetségi oktatási minisztérium 2004-ben indított el egy „Leadership Academy" (LEA) elnevezésü megaprojektet, amelynek célja az osztrák oktatásügyi vezetők gondolkodásának és attitüdjeinek átformálása annak érdekében, hogy hivatali végrehajtókból és a jogszerüség őreiből olyan vezetővé váljanak, akik képesek kreatív módon irányítani az önálló és adaptív szervezetként müködő intézményeket (Stoll et al., 2008). Szimbolikus súlya van annak, hogy e képzési programnak, amelyben 2007 végéig több mint ezer iskolavezető vett részt, nincs német neve. E program természetéröl - arról, hogy mennyire közvetlenül a tanuláscentrikus vezetés fejlesztését kívánja szolgálni - talán az mondja el a legtöbbet, hogy saját tanulásszervezési megoldásaiban is határozottan a tanulásról való modern gondolkodásra épít (lásd a keretes írást).

\footnotetext{
${ }^{14}$ Ilyen például a ,School Improvement Partners” elnevezésű program, amely a legjobb iskolák igazgatóit felkészíti arra, hogy kevésbé jó iskolák „feljavításában” részt vegyenek (NCSL, 2008).

${ }^{15}$ Lásd a szervezet honlapját: http://www.ncsl.org.uk/aboutus-index/about-role-index.htm
} 


\section{Az osztrák Leadership Academy (LEA) saját tanulási és tanítási modellje}

„A LEA a vezetési képességek megtanulását olyan komplex feladatnak tekinti, amely időigényes és csak több, egymást követő interakció során lehetséges. A résztvevőknek nyújtott prezentációk, az általános tanuláselméletnek és a felnőttek tanulásáról szóló elméleteknek megfelelően, a tanulók meglévő előzetes tudására építenek, és kombinálják az akadémikus és a tapasztalatalapú folyamatokat a tudás felépítésében (combining academic and experiential processes to construct new knowledge). Az új anyagok és gyakorlatok egymást logikusan és koherensen követő szekvenciákra épülnek annak érdekében, hogy létrejöjjenek az eredményes tanulás érzelmi és intellektuális feltételei. A kiinduló elméleti konstrukció az, hogy a programot meghatározó alapelveknek megfelelően szervezett tréning és tapasztalatszerzés olyan tanulást eredményez, amelyet a részt vevő iskolavezetők eredményesen tudnak majd alkalmazni a saját iskolájukban. E tanulási modell kulcselemei:

- az új gondolatok fokozatos elővezetése (lehetőleg a résztvevők által jól ismert kontextusban);

- a résztvevők saját tudásának és tapasztalatainak aktivizálása;

- demonstrálás és modellezés;

- gyakori lehetőség a közös vitára és az alkalmazások gyakorlására;

- a tanulás hozzákapcsolása a résztvevők saját szervezetében megvalósuló projektekhez és ott jelentkező problémákhoz;

- különbözö tanulási stílusokhoz alkalmazkodó, többféle megközelítés alkalmazása;

- intellektuális és érzelmi támogatás biztosítása, gyakori visszajelzések, a biztonságérzetet nem sértö korrekciók, bizalmon alapuló légkör;

- olyan szakmai tanulást folytató gyakorlatközösség létrehozása, amely képes biztosítani a tanulás és a változás fenntarthatóságát" (Stoll et al., 2008, 223 224. o.).

A konkrét országokra utaló példákat talán érdemes azzal zárni, hogy a magyarországi fejlesztök és elemzők közül is többen felismerték a vezetésnek és a szervezeti folyamatoknak a szerepét a tanulás eredményesebbé tételében, és bizonyos elemek beépültek a hivatalos állami fejlesztési programokba. A szervezetfejlesztés és a tanulásfejlesztés közvetlen összekapcsolására történtek koncepcionális próbálkozások (Bognár, 2004), és e két terület szoros kapcsolatának felismerése a beépült az oktatásügyi folyamatok értékelésébe (Golnhofer és Szekszárdi, 2003). A két terület közötti kapcsolatteremtés szükségességét különböző szakmai rendezvényeken gyakran megfogalmazták (Révész és Szabó, 2008), és több, konkrét fejlesztő beavatkozásban is érvényesítették. Ez jellemezte például a holland-magyar a bilaterális 
együttmüködés keretei között 2003 és 2006 között folyt „Megelőzés - alkalmazkodás - gondoskodás" (MAG) elnevezésủ fejlesztési programot ${ }^{16}$, a fenntarthatóságot támogató „Ökoiskola” programot, ${ }^{17}$ vagy később az uniós forrásokra épülő kompetenciafejlesztést célzó programokat (Békési és Szabó, 2008).

\section{Oktatási innovációs politikák}

A vezetés- és szervezetfejlesztés előtérbe helyezése mellett a tanuláscentrikus oktatáspolitikák másik fontosabb eszköze olyan ágazati kutatási-fejlesztési politikák megfogalmazása és megvalósítása, amelyek előterében az innováció áll. Ennek két egyformán fontos elemét kell hangsúlyozni: az egyik általában az oktatási ágazati kutatás-fejlesztési tevékenység felértékelése, a másik ezen belül az innovációs dimenzió előtérbe helyezése, vagyis lényegében a $\mathrm{K}+\mathrm{F}$ politika átalakítása $\mathrm{K}+\mathrm{F}+\mathrm{I}$ politikává. Az utóbbit különösen erősen kell hangsúlyozni, hiszen egyáltalán nem minden oktatási ágazati $\mathrm{K}+\mathrm{F}$ politika kedvez a tanuláscentrikus oktatáspolitikáknak.

Érdemes felfigyelnünk arra, hogy mindazokban az országokban, amelyek tanuláscentrikus oktatáspolitikákat próbálnak megvalósítani, az oktatási ágazatra hagyományosan jellemző az erős kutatási-fejlesztési orientáció, illetve erőfeszítések történtek és történnek a nemzeti oktatáskutatási-fejlesztési rendszerek megújítására és megerősítésére. Az amerikai NCLB törvény négy pillérjének például egyike volt a „tudományosan megalapozott pedagógiai módszerek” (Proven Education Methods) támogatása, és nem sokkal e törvény elfogadását követően elfogadtak egy másikat is, amely az oktatáskutatásokról szólt. ${ }^{18}$ Ez teljesen új alapokra helyezte az oktatáskutatást és új intézmények létrehozását eredményezte. Egy másik példa az Egyesült Királyság, ahol 1999-ben az akkori oktatási miniszter létrehozott egy új szervezetet (National Educational Research Forum - NERF) ${ }^{19}$ amelynek az volt a feladata, hogy dolgozza ki az oktatási szektor saját kutatási-fejlesztési stratégiáját (Morris és Peckham, 2006). Ez meg is történt, és e stratégia jelenleg (2009-ben) is orientálja az ottani oktatáspolitikát.

E tanulmány témáját tekintve a nemzeti kutatási, fejlesztési és innovációs rendszerek megújításának három alapvető jellemzőjét tünik érdemesnek kiemelni. Az első - amire már utaltam - a K+F+I rendszereken belül az innovációs elem elötérbe helyezése, a második a tényeken alapuló fejlesztés, a harmadik pedig a kutatásfejlesztés és a gyakorlat közötti közvetitő mechanizmusok megerősítése (ami, mint látni fogjuk, nagyon szorosan kötődik az első jellemzőhöz). Néhány szót mind a háromról szükséges itt elmondani, jelezve azt, hogy ezek miképpen támogatják a tanuláscentrikus oktatáspolitikákat.

\footnotetext{
${ }^{16}$ A program honlapját lásd itt: http://www.oki.hu/mag.php

${ }^{17}$ A program honlapját lásd itt: http://www.okoiskola.hu/

${ }_{18}^{18}$ Lásd: Education Sciences Reform Act of 2002 (http://www.ed.gov/policy/rschstat/leg/PL107-279.pdf).

${ }^{19}$ A szervezet honlapját lásd itt: http://www.eep.ac.uk/nerf/index.html
} 
Az innovációs elemnek a $\mathrm{K}+\mathrm{F}+\mathrm{I}$ rendszereken belül történő kiemelése (aminek egészen radikális formája akár a kutatási politikának innovációs politikával történő helyettesítése is lehet), az oktatáskutatást hozzákapcsolja az olyan nemzeti innovációs politikákhoz, amelyek általában igen közvetlen gyakorlati célokat szolgálnak (a nemzetgazdaság, illetve a vállalatok piaci versenyképességének erösítését). Ez szorosan kötődik a tudományos kutatásról való gondolkodásnak ahhoz az átalakulásához, amelyet Gibbons (Gibbons et al., 2000) nyomán „Mode 2” kutatásként szoktunk leírni. Az innovációs politikáról való mai gondolkodás többek között azért kedvez a tanuláscentrikus oktatáspolitikának, mert ebben kiemelt szerepet kapnak a felhasználók, a megújítandó tevékenység tényleges végzői (jelen esetben a tanárok), akik például nem várnak arra, hogy a kutatók vagy fejlesztők kívülröl szállítsák számukra a munkavégzésükhöz szükséges új technológiát, hanem saját maguk próbálják azt folyamatosan megújítani (OECD, 2004; Bentley és Gillinson, 2007). Azok az intelligens tanulószervezetként müködő iskolák, amelyekről korábban szó volt, mindig innovatív iskolák is. Fontos ehhez persze hozzátenni, a tanulás természetének a megértésén alapuló innováció nemcsak az osztálytermekben folyik, hanem azokban a mühelyekben is, ahol országos szinten terjesztett tanulásszervezési technológiákat (például programcsomagokat) hoznak létre.

A tényeken alapuló fejlesztő vagy oktatáspolitikai gyakorlat elve (evidence based practice) a fejlett országokban az elmúlt egy évtizedben jutott el az egészségügy vagy a gyógyítás világából az oktatás világába, többek között éppen az amerikai NCLB politika részeként (Halász, 2008b). Ennek itt egy elemét érdemes kiemelni: ez a megközelítés a dolgok gyakorlatban történő kipróbálását, a kísérleteken alapuló igazolást hangsúlyozza (szemben más kutatási módszerekkel, így a kipróbálási elemet nélkülöző, pusztán adatfelvételeken alapulóval szemben). A tanuláskutatás eredményeire épülő tanuláscentrikus oktatáspolitikák számára ez azért fontos, mert ez éppen a tanulás végtelen komplexitásából indul ki, és elfogadja azt a gyakorlati elvet, hogy csak arról ('́gy arról a pedagógiai eljárásról) mondhatjuk biztosan, hogy müködik, amit a gyakorlatban ténylegesen kipróbáltunk - kipróbálást szigorú protokollokban rögzített standardok szerint végezve (Cook és Gorard, 2007).

A nemzeti kutatási, fejlesztési és innovációs rendszerek megújításának harmadik fontos eleme a kutatás-fejlesztés és a gyakorlat közötti közvetítő mechanizmusoknak a megerősítése. Ez, mint láthattuk, ott volt már a korábban említett két másik elemben is, de önállóan is hangsúlyt kap. Ennek jellegzetes példája a korábban idézett angol Tanitás- és Tanuláskutatás Program, amellyel kapcsolatban említettem, hogy ennek célja nem egyszerủen a tudományos ismeretek mennyiségének a növelése, hanem a tanuláskutatás és az oktatáspolitika, illetve iskolák közötti kapcsolat erősítése. Ez a cél olyan új intézmények létrehozásában is testet ölt, amelyeket közvetítő ügynökségeknek (brokerage agencies) neveznek, és amelyeknek célja a kutatók és a gyakorlati szakemberek közötti kommunikációs szakadékok áthidalása (Burns és Schuller, 2007). 
Az oktatási innovációs politikák, mint láthattuk, azért válnak a tanuláscentrikus oktatáspolitikák egyik legnagyobb erejü eszközévé, mert átalakítják a tudás termelésének, terjesztésének és hasznosításának korábbi modelljeit, és lehetővé teszik, hogy az a tudás, amelyet a tanuláskutatás az emberi tanulás természetéröl megteremtett - és teremt ma is - valóban az iskolai és osztálytermi gyakorlat közvetlen megújítójává váljék. Az innovációs kényszer beszükíti annak a lehetőségét, hogy az iskolák rutinszerúen folytassák az oktatás megszervezésének azt a bürokratikus logikára épülő gyakorlatát, amely alig vett tudomást az emberi tanulás valóságos természetéröl. A tanuláscentrikus oktatáspolitikákban szorosan összekapcsolódik egymással a vezetési és szervezeti dimenzió hangsúlyozása és az innováció felértékelése: ezek egymást kölcsönösen erösítve teszik lehetővé azt, hogy a tanuláskutatás eredményei a tanulás tényleges megújítását szolgálhassák.

\section{Konklúzió}

E tanulmány elején különbséget tettem a tanulás kétféle (,formális” vagy „iskolás” és ,autentikus”) formája között, és hangsúlyoztam, hogy számos országban olyan oktatáspolitikák kialakulásának vagyunk a tanúi, amelyek megpróbálják elérni, hogy az iskolák az utóbbira törekedjenek. E törekvésnek sokféle oka van, amelyek egyike az emberi tanulásról való tudásunk változása. Megpróbáltam érzékeltetni, milyen kihívásokkal és veszélyekkel kell szembenéznie minden olyan oktatáspolitikának, amely komolyan megcélozza az „autentikus” tanulást, és nem akar letenni arról, hogy minden egyes tanuló képességei komolyan fejlődjenek. Kiemeltem azt, hogy a tanulás eredményességét és a tanuláskutatás eredményeit egyaránt komolyan vevő „tanuláscentrikus” oktatáspolitikáknak szembe kell nézniük a tanulás rendkívüli komplexitásával. E komplexitást az oktatáspolitikák csak akkor tudják kezelni, ha képesek minden egyes iskolát intelligens, a tanulással kapcsolatos problémák sokaságának megértésére és megoldására képes szervezetté tenni. Önmagában az iskolák elé állított standard követelményeknek a megerösítése és ezek teljesítésének szankcionálása nem eredményezheti a tanulás komolyan vételét. A tanuláscentrikus oktatáspolitikával próbálkozó országoknak egy része ezt felismerte, és sikeres eröfeszítéseket tett értékelési rendszerének oly módon történő átalakítására, hogy az összhangba kerüljön a tanulásfejlesztés céljaival. Ezen túlmenően ezek az országok a tanulásfejlesztés egyik fontos eszközévé tették a szervezet- és vezetésfejlesztést is, abban bízva, hogy ennek segítségével válhatnak az iskolák a magas szintü komplexitás kezelésére képes intelligens szervezetekké. Ezekben az országokban a szervezet- és vezetésfejlesztés többek között azért válhat képessé a tanulás eredményesebbé tételére, mert szorosan összekapcsolódik a tanuláskutatás eredményeinek mindennapos gyakorlati hasznosításával, amit az oktatási ágazat kutatási, fejlesztési és innovációs politikájának a megerősítése és megújítása segít. 


\section{Irodalom}

Akker, Jan van den (2005): Curriculum development re-invented: evolving challenges. In: Jos Letschert (ed.): Curriculum development re-invented. SLO - Netherlands Institute for Curriculum development. Enschede, 16-30.

Allais, S. M. (2007): Why the South African NQF Failed: lessons for countries wanting to introduce national qualifications frameworks. European Journal of Education, (42) 4 , 523-547.

Ashton, D., Sung, J., Turbin, J. (2000): Towards a Framework for the Comparative Analysis of National Systems of Skill Formation. International Journal of Training and Development, (4) 1, 8-25.

Békési Kálmán, Szabó Mária (2008): A kompetencia alapú programcsomagok magyarországi fejlesztésének előzményei. In: Zsigovits Gabriella (szerk.): Kompetenciafejlesztés 2004-2008. Tények és vélemények. Educatio Kht, Budapest, 11-32.

Bentley, T., Gillinson, S. (2007): A D\&R system for education. The Innovation Unit. London.

(http://www.innovation-unit.co.uk/images/stories/files/pdf/d_and_r_system_for_education. pdf)

Black, P., Wiliam, D. (1998): Inside the Black Box. Raising Standards through Classroom Assessment. Phi Delta Kappan, (80) 2, 139-148.

Bognár Mária (2004): Oktatásfejlesztés, iskolafejlesztés az ezredfordulón. Új Pedagógiai Szemle, 1. sz. 40-58.

Burns, T., Schuller, T. (2007): The Evidence Agenda. In: OECD: Evidence in Education: Linking Research and Policy. Paris, 15-32.

Colardyn, D., Bjornavold, J. (2004): Validation of Formal, Non-Formal and Informal Learning: policy and practices in EU Member States. European Journal of Education, (39) 1, 69-89.

Cowan, J. (2004): Education for higher level capabilities. Beyond alignment, to integration? In: Gill, V. M. S., Alarcao, I., Hooghof, H.: Challenges in Teaching and Learning in Higher Education. SLO - University of Aveiro. Enshede - Aveiro, 53-76.

Cook, Th., Gorard, S. (2007): What Counts and What Should Count as Evidence. In: OECD: Evidence in Education: Linking Research and Policy. Paris, 33-49.

Delamare le Deist, F., Winterton, J. (2005): What Is Competence? Human Resource Development International, (8) 1. 27-46.

Elmore, R. (2000): Building a new structure for school leadership. The Albert Shanker Institute. Washington. (http://www.shankerinstitute.org/Downloads/building.pdf)

Elmore, R. (2008): Leadership as the practice of improvement. In: Pont, B. - Nusche, D., Moorman, H. (2008): Improving School Leadership. OECD. Paris. 37-67.

European Commission (2007): Commission Staff Working Paper Schools for the 21st Century. Brussels, 11. 07. 07. SEC(2007)1009

Fullan, M. (2008): Változás és változtatás - III. A ráadás. Oktatáskutató és Fejlesztő Intézet, Budapest. 
Gibbons, M., Limoge, C., Nowontny, H., Schwarzman, S., Scott, P., Trowm M. (2000): The new production of knowledge. Sage Publications, London, Thousand Oaks, New Delhi.

Golnhofer Erzsébet, Szekszárdi Júlia (2003): Az iskolák belső világa. In: Halász Gábor, Lannert Judit (szerk.): Jelentés a magyar közoktatásról - 2003. Országos Közoktatási Intézet, Budapest, 239-270.

Gordon Győri János (2002): A tanárképzés és tanártovábbképzés japán modellje. Magyar Pedagógia, 4. sz. 491-515.

(http://www.edu.u-szeged.hu/mped/document/janos_gyri-some_special_features_of_ preservice_and_inservice_teacher_training_in_japan.pdf)

Gordon Győri János (2007): Tanórakutatás (lesson study). Egy elterjedőben lévő oktatásfejlesztési módszer magyarországi adaptációjának kérdései. Új Pedagógiai Szemle, 2. sz. 15-23.

(http://www.oki.hu/oldal.php?tipus=cikk\&kod=2007-02-ta-Gordon-Tanorakutatas)

Halász Gábor (2008a): Képességfejlesztés, iskolavezetés és pedagógiai paradigmaváltás. In: Kiss Éva (szerk.): Pedagógián innen és túl. Zsolnai József 70. születésnapjára. Pannon Egyetem BTK, Pécsi Tudományegyetem BTK, 366-387.

(http://www.oki.hu/halasz/download/Iskolavezetes\%20es\%20tanulas.htm)

Halász Gábor (2008b): Tényekre alapozott oktatáspolitika. Kézirat. Készült a magyar miniszterelnök által összehívott Oktatási Kerekasztal titkárságának a megbízásából. (http://www.oki.hu/halasz/download/Evidence\%20based\%20study.mht)

Hallinger, P., Heck, R. (1998): Exploring the Principal's Contribution to School Effectiveness: 1980-1995. School Effectiveness \& School Improvement, (9) 2, 157-191.

Hopkins, D. (2004): Kiválóság és méltányosság - az angol oktatási rendszer jellemzői. Új Pedagógiai Szemle, 12. sz. 16-25.

(http://www.oki.hu/cikk.php?kod=2004-12-ko-Hopkins-Kivalosag.html)

Jörg, T. (2004): Complexity Theory and the Reinvention of Reality of Education. Paper presented at the Complexity Science and Educational Research Conference. 2004 Kingston. 30 September-3 October (http://www.uu.nl/uupublish/content/paperKingstondef.pdf).

Kováts Gergely (2002): A vállalati egyetem. Szakdolgozat. Budapesti Közgazdaságtudományi és Államigazgatási Egyetem Vezetési és Szervezési Tanszék. Kézirat.

KSH (2007): A munkahelyi képzések föbb adatai. Statisztikai Tükör, 14. sz.

Levin, B. (2001): Conceptualizing the Process of Education Reform From An International Perspective. Education Policy Analysis Archives, (9) 14, (http://epaa.asu.edu/epaa/v9n14.html)

Marton, F. (2004): A tanulás tárgya. Magyar Pedagógia, 4. sz. 381-392. (http://www.magyarpedagogia.hu/document/Marton_MP1044.pdf)

Ministry of Education (2007): The New Zealand Curriculum. Wellington. http://nzcurriculum.tki.org.nz/the_new_zealand_curriculum) 
Morris, A., Peckham, M. (2006): Final Report of the National Educational Research Forum. NERF Working Paper 9.2.

(http://www.eep.ac.uk/nerf/word/wp9.2NERFFinalReporte42d.doc?version=1)

Mulford, B., Silins, H. (2003): Leadership for Organisational Learning and Improved Student Outcomes - What we know. Cambridge Journal of Education, (33) 2, 175-195.

Nahalka István (1998): A tanulás. In: Falus Iván (szerk.): Didaktika. Nemzeti Tankönyvkiadó, Budapest, 117-158.

NCSL (2008): NCSL Prospectus. National College for School Leadership. (http://www.ncsl.org.uk/media-a88-50-ncsl-prospectus-2009.pdf)

OECD (2004): Knowledge Management Innovation in the Knowledge Economy. Implications for Education and Learning, Paris.

Partners in Education Transformation (2009): Transforming Education: Assessing and Teaching 21st Century Skills. Assessment Policy Brief, Cisco - Intel - Microsoft (http://www.latwf.org/docs/Assessment_Policy_Brief.pdf)

Perjés István, Vass Vilmos (2008): A curriculumelmélet müfaji fejlődése. Új Pedagógiai Szemle, 3. sz. 3-9.

Pollard, A. (2007): The United Kingdom's Teaching and Learning Research Programme. In: Evidence in Education: Linking Research and Policy. OECD, Paris, 125-130.

Révész Éva, Szabó Mária (2008): The role of school leadership in creating a learning environment that is conductive to effective learning with special regard to the improvement of the quality of teacher activity. National report - Hungary. Manuscript.

Robinson, V. M. J. (2007): School Leadership and Student Outcomes: Identifying What Works and Why. ACEL Monograph Series. 41.

(http://www.educationcounts.govt.nz/_data/assets/pdf_file/0020/13727/Leadership_ Oration.pdf)

Sawyer, R. K. (2008): Optimizing Learning: Implications of Learning Sciences Research. OECD/CERI International Conference „Learning in the 21 st Century: Research, Innovation and Policy”. Paris. (http://www.oecd.org/dataoecd/39/52/40554221.pdf)

Schuur, K., Feenstra, B., Duvekot, R. (2005): European Learning cultures \& VPL. In: Duvekot, R., Schuur, K., Paulusse, J. (Eds.): The Unfinished Story of VPL. Foundation EC-VPL \& Kenniscentrum EVC. Utrecht, 29-116.

Seashore, K. L., Wahlstrom, K. L. (2008): How Teachers Experience Principal Leadership: The Roles of Professional Community, Trust, Efficacy, and Shared Responsibility. Educational Administration Quarterly, (44) 4, 458-495.

Sliwka A. (2005): Networking for Educational Innovation: A Comparative Analysis. In: OECD: Networks of Innovation Towards New Models for Managing Schools and Systems. Paris, 49-63. (http://www.oecd.org/dataoecd/22/62/41283632.pdf)

Sliwka, A. (2008): The Contribution of Alternative Education. In: Innovating to Learn, Learning to Innovate. OECD, Paris, 93-112.

Stoll, L., Moorman, H., Rahm, S. (2008): Building leadership capacity for system improvement in Austria. In: Pont, B. - Nusche, D., Moorman, H. (Eds.): Improving School Leadership. OECD, Paris, 215-250. 
TLRP (2008): Ten evidence-informed pedagogic principles. Teaching and Learning Research Programme. (http://www.tlrp.org/themes/themes/tenprinciples.html)

TUC (2008): National Employers Skills Survey. TUC Organisation \& Services Department. May 2008 (http://www.tuc.org.uk/skills/tuc-14768-f0.pdf)

US department of education (2004): Four Pillars of NCLB. (http://www.ed.gov/nclb/overview/intro/4pillars.html)

World Class Skills (2007): Implementing the Leitch Review of Skills in England. Presented to Parliament by the Secretary of State for Innovation. Universities and Skills by Command of Her Majesty, July 2007.

Young-Hyun, Lee (2007): Workforce Development in the Republic of Korea. Asian Development Bank Institute, Tokyo. 